\title{
PRODUCTIVE PERFORMANCE OF VERNALIZATED SEMI-NOBLE GARLIC CULTIVARS IN WESTERN RIO GRANDE DO NORTE STATE, BRAZIL ${ }^{1}$
}

\author{
RAFAELLA RAYANE MACEDO DE LUCENA ${ }^{2 *}$, MARIA ZULEIDE DE NEGREIROS ${ }^{2}$, FRANCISCO VILELA \\ RESENDE $^{3}$, WELDER DE ARAUJO RANGEL LOPES ${ }^{2}$, OTACIANA MARIA DOS PRAZERES DA SILVA ${ }^{2}$
}

\begin{abstract}
The objective of this work was to evaluate the development and production of semi-noble garlic cultivars subjected to different bulb-seed pre-planting vernalization periods in two municipalities (Barauna and Governador Dix-sept Rosado) of the Western Mesoregion of Rio Grande do Norte State, Brazil. Therefore, two simultaneous experiments were conducted, from April to November, 2012. A complete randomized block experimental design was used with four replications. The treatments were arranged in split-plot design, with the plots consisted of cultivars (Gigante-do-Nucleo and BRS-Hozan) and subplots consisted of bulb-seed preplanting vernalization $\left(4 \pm 1^{\circ} \mathrm{C}\right)$ periods $(0,10,20$ and 30 days). In Barauna, the cultivar Gigante-do-Nucleo proved to be adapted, with a yield of $4.56 \mathrm{Mg} \mathrm{ha}^{-1}$ without vernalization, while the BRS-Hozan presented a yield of $4.42 \mathrm{Mg} \mathrm{ha}^{-1}$ when vernalizated for 10 days at pre-planting. In Governador Dix-sept Rosado, the vernalization of 10 days improved the adaptation of both cultivars, however, with no significant yield increases. The use of vernalization improved adaptation of cultivars in the planting locations, facilitating the emergence of plants, increasing plant height and number of leaves, however, not promoting significant yield increases, therefore, this technology should not be used for produce this type of garlic in this region.
\end{abstract}

Keywords: Allium sativum L. Refrigeration. Yield.

\section{DESEMPENHO PRODUTIVO DE CULTIVARES DE ALHO SEMI-NOBRE VERNALIZADAS NA MESORREGIÃO OESTE POTIGUAR}

\begin{abstract}
RESUMO - Com o presente estudo, objetivou-se avaliar o desenvolvimento e a produção de cultivares de alho semi-nobre, submetidas a diferentes períodos de vernalização pré-plantio dos bulbos-semente em dois municípios da Mesorregião Oeste Potiguar. A pesquisa constou de dois experimentos desenvolvidos, simultaneamente, em Baraúna/RN e Governador Dix-sept Rosado/RN, entre os meses de abril e novembro de 2012. O delineamento experimental foi o de blocos completos casualizados com quatro repetições. Os tratamentos foram dispostos em parcelas subdivididas, sendo as parcelas representadas pelas cultivares Gigante do Núcleo e BRS Hozan e as subparcelas constituídas pelos períodos de vernalização pré-plantio dos bulbossemente a $4 \pm 1{ }^{\circ} \mathrm{C}$ : 0, 10, 20 e 30 dias. Em Baraúna, a cultivar Gigante do Núcleo mostrou-se adaptada, apresentando uma produtividade de 4,56 $\mathrm{t} \mathrm{ha}^{-1}$ sem o uso da vernalização, enquanto a cultivar BRS Hozan obteve uma produtividade de 4,42 $\mathrm{t} \mathrm{ha}^{-1}$ quando vernalizada por 10 dias em pré-plantio. Em Governador Dixsept Rosado, a vernalização de até 10 dias melhorou a adaptação de ambas as cultivares, entretanto, sem aumentos significativos na produtividade. O uso da vernalização, embora tenha melhorado a adaptação das cultivares nos locais de plantio, favorecendo a emergência de plantas, a altura de plantas e o número de folhas, não proporcionou aumentos significativos na produtividade, e, portanto, essa tecnologia não deve ser utilizada para produção deste tipo de alho na região.
\end{abstract}

Palavras-Chave: Allium sativum L. Frigorificação. Produção.

\footnotetext{
*Corresponding author

${ }^{1}$ Received for publication in $01 / 26 / 2015$; accepted in $02 / 12 / 2016$.

Paper extracted from the doctoral thesis of the first author.

${ }^{2}$ Department of Plant Sciences, Universidade Federal Rural do Semi-Árido, Mossoró, RN, Brazil; rafaellarayane@hotmail.com, zuleide@ufersa.edu.br, welder.lopes@hotmail.com, otaciana_silva@yahoo.com.br.

${ }^{3}$ National Center for Vegetable Crops Research, Empresa Brasileira de Pesquisa Agropecuária, Brasília, DF, Brazil; francisco.resende@embrapa.br.
} 


\section{INTRODUCTION}

Garlic (Allium sativum L.) is a vegetable with great economic and social importance in Brazil, because it is grown mainly by small farmers and requires workforce in large-scale (LIMA et al., 2008). The use of garlic has been found in pharmacology, human and animal nutrition and agriculture, in both fresh and industrialized forms, as well as in the biological control of pests (CUNHA, 2011).

Despite the importance of garlic crop in Brazil, the country is the world's largest importer, with China and Argentina as its main suppliers (LUCINI, 2014; SPOTO; GUTIERREZ, 2012). However, national yield has shown a gradual increase in recent years, due to the development of new technologies and more productive varieties of garlic, which allowed the crop expansion to new planting areas in some regions (OLIVEIRA et al., 2010).

The Rio Grande do Norte State depends on imports to meet the demand of this product. Even with little crop area and amount of produced garlic, by the end of the $1980 \mathrm{~s}$, the state supplied part of its demand at harvest times, from August to December, depending on the planting season. The only municipality producer of garlic in the State at that time, was the Governador Dix-sept Rosado, where crops were conducted mainly alongside the Mossoró River by low-income producers, using rudimentary techniques. Thus, the planting season depended on the lowering of the water, which were often in September, when rising temperatures compromised the production and quality of teh produced bulbs. The creation of MERCOSUR facilitated the import of Argentine garlic, and later the Chinese garlic, therefore, those crops lost competitiveness and were no longer produced in the State (SOARES, 2013).

Garlic crop requirements related to photoperiod and temperature are the factors that most affect these crops. The existing cultivars differ in photoperiod and temperature requirements, thus allowing flexibility regarding the time and planting location. The adoption of the vernalization practice in recent years has enabled the planting of noble garlic cultivars from Argentina and South of Brazil in regions where the thermo-photoperiodic conditions does not meet the plant requirements. There are great differences between cultivars regarding the reactions to vernalization, with differences in crop cycle, plant appearance, predisposition to secondary tillering, post-harvest conservation, yield and commercial quality (MACÊDO et al., 2009).

Vernalization applied to common and seminoble garlic cultivars has proven to be harmful in regions where these varieties are adapted. Significant reductions in development and crop yield has been observed in these cases. The semi-noble cultivars, especially, have little adaptation to the Brazilian Northeast, as verified by Honorato et al. (2013) and Soares (2013), who found low rates of bulbs with different bulbils and low yield. This result suggests that short vernalization periods (less than 30 days) may increase the semi-noble garlic adaptability to the Northeast, similar to noble garlic, which had its crop area extended from the South to other regions of Brazil when vernalizated.

The adoption of high-yield cultivars that have better market acceptance, and the adjustments in vernalization technology, which is a key aspect for adaptation of new cultivars, may contribute to revitalize garlic crops in areas that previously produced this vegetable. In this context, the objective of this work was to evaluate the development and production of semi-noble garlic cultivars subjected to different bulb-seed pre-planting vernalization periods in two municipalities (Barauna and Governador Dixsept Rosado) of the Western Mesoregion of Rio Grande do Norte State, Brazil.

\section{MATERIAL AND METHODS}

Two experiments were simultaneously conducted and equally managed at two locations of the Western Mesoregion of Rio Grande do Norte State $(\mathrm{RN})$, Brazil, between April and November 2012.

The first experiment was conducted at Santa Luzia Farm, Community of Juremal, municipality of Barauna RN, in a soil classified as medium textured haplic Cambisol (EMBRAPA, 2006), which had, according to chemical analysis of soil samples collected at $0-20 \mathrm{~cm}$ of depth, the following characteristics: $\mathrm{pH} \mathrm{H}_{2} \mathrm{O}=5.80, \mathrm{P}=2.70 \mathrm{mg} \mathrm{dm}^{-3}$, $\mathrm{K}=216.00 \mathrm{mg} \quad \mathrm{dm}^{-3}, \quad \mathrm{Na}=5.80 \mathrm{mg} \mathrm{dm}^{-3}$, $\mathrm{Ca}=4.69 \mathrm{cmol}_{\mathrm{c}} \quad \mathrm{dm}^{-3}, \quad \mathrm{Mg}=0.93 \quad \mathrm{cmol}_{\mathrm{c}} \quad \mathrm{dm}^{-3}$, $\mathrm{Al}=0.00 \mathrm{cmol}_{\mathrm{c}} \mathrm{dm}^{-3}$ and $\mathrm{MO}=7.79 \mathrm{~g} \mathrm{~kg}^{-1}$. Barauna $\left(5^{\circ} 04^{\prime} \mathrm{S}, 37^{\circ} 37^{\prime} \mathrm{W}\right.$ and $120 \mathrm{~m}$ of altitude), has photoperiod with little variation along the year, around 12 hours. The mean temperature and relative humidity measured during the experimental period were $26.6^{\circ} \mathrm{C}$ and $59.1 \%$, respectively.

The second experiment was conducted at Santana Farm, municipality of Governador Dix-sept Rosado RN, in a soil classified as medium textured eutrophic Fluvisol (EMBRAPA, 2006), which had, according to chemical analysis of soil samples collected at $0-20 \mathrm{~cm}$ of depth, the following characteristics: $\mathrm{pH} \mathrm{H}_{2} \mathrm{O}=7.78, \mathrm{P}=382.40 \mathrm{mg} \mathrm{dm}^{-3}$, $\mathrm{K}=153.2 \mathrm{mg} \mathrm{dm}^{-3}, \quad \mathrm{Na}=16.10 \mathrm{mg} \mathrm{dm}^{-3}$, $\mathrm{Ca}=7.03 \quad \mathrm{cmol}_{\mathrm{c}} \quad \mathrm{dm}^{-3}, \quad \mathrm{Mg}=0.80 \quad \mathrm{cmol}_{\mathrm{c}} \quad \mathrm{dm}^{-3}$, $\mathrm{Al}=0.00 \quad \mathrm{cmol}_{\mathrm{c}} \quad \mathrm{dm}^{-3}$ and $\mathrm{MO}=10.90 \mathrm{~g} \mathrm{~kg}^{-1}$. Governador Dix-sept Rosado $\left(5^{\circ} 27^{\prime} \mathrm{S}, 37^{\circ} 31^{\prime} \mathrm{W}\right.$ and $34 \mathrm{~m}$ of altitude) has also photoperiod with little variation along the year, around 12 hours. The mean temperature and relative humidity measured during the experimental period were $28.6^{\circ} \mathrm{C}$ and $55.9 \%$, respectively. 
A complete randomized block experimental design was used with four replications. The treatments were arranged in split-plot design, where the plots consisted of the cultivars (Gigante-doNucleo and BRS-Hozan) and subplots consisted of the bulb-seed pre-planting vernalization periods (0, 10, 20 and 30 days). The bulb-seeds underwent vernalization process, cold stored at temperature of $4 \pm 1^{\circ} \mathrm{C}$ and relative humidity of $75 \pm 5 \%$, before planting, which was performed at May 18 (Barauna) and 21 (Governador Dix-sept Rosado), 2012. The bulb-seeds from each treatment were subjected to the cold chamber in an order that allowed the planting of the bulbils in all subplots at the same time.

After the vernalization period, the bulb-seeds were removed from the chamber for threshing and classification of bulbils. The bulbils retained in sieves 1 and 2 were planted in blocks 1 and 2 and those retained in the sieve 3 planted in blocks 3 and 4 , in order to reduce variations within each block (HONORATO et al., 2013).

The subplot beds were $0.20 \mathrm{~m}$ high, $1.0 \mathrm{~m}$ wide and $2.0 \mathrm{~m}$ long, with five planting rows. The bulbils were planted at a depth of $0.05 \mathrm{~m}$, spaced $0.20 \mathrm{~m}$ between rows and $0.10 \mathrm{~m}$ between plants, with total area of $2.0 \mathrm{~m}^{2}$ and evaluation area of 1.08 $\mathrm{m}^{2}$, totaling 100 plants and 54 assessed plants per subplot.

Soil preparation consisted of plowing and harrowing, followed by preparation of the beds. Fertilization at planting was performed based on the soil analysis and suggestions from Cavalcanti (2008) and Resende et al. (2004) for the garlic crop in both locations. Fertilization at planting was performed with $40 \mathrm{Mg} \mathrm{ha}^{-1}$ Pole Fertil (based on cattle and chicken manure), $30 \mathrm{~kg} \mathrm{ha}^{-1} \mathrm{~N}$ (ammonium sulfate), $60 \mathrm{~kg} \mathrm{ha}^{-1} \mathrm{P}_{2} \mathrm{O}_{5}$ (superphosphate), $20 \mathrm{~kg} \mathrm{ha}^{-1} \mathrm{~K}_{2} \mathrm{O}$ (potassium chloride), $15 \mathrm{~kg} \mathrm{ha}^{-1} \mathrm{Mg}$ (magnesium sulfate) $7 \mathrm{~kg} \mathrm{ha}^{-1} \mathrm{Zn}$ (zinc sulphate) and $1.7 \mathrm{~kg} \mathrm{ha}^{-1} \mathrm{~B}$ (boric acid). Two topdressing fertilization applications were performed, 30 days after planting with $30 \mathrm{~kg} \mathrm{ha}^{-1} \mathrm{~N}$ (urea) and $20 \mathrm{~kg} \mathrm{ha}^{-1}$ of $\mathrm{K}_{2} \mathrm{O}$ (potassium chloride), and 60 days after planting with $30 \mathrm{~kg} \mathrm{ha}^{-1} \mathrm{~N}$ (urea).

A micro-sprinkler irrigation system was used with two micro-sprinklers per subplot, water flow rate of $27 \mathrm{~L} \mathrm{~h}^{-1}$ and pressure of $200 \mathrm{kPa}$, estimating the amount of water applied according to crop evapotranspiration (ALLEN et al., 1998), taking into account the reference evapotranspiration $\left(\mathrm{ET}_{0}\right)$ and the crop Kc for each development stage. Tensiometers were installed at 0.15 and $0.30 \mathrm{~m}$ deep, in two replications of each experiment, in order to monitor the soil moisture during the experimental period.

Prevention and control of diseases, such as the purple blotch was performed with a Mancozeb based product (Manzate ${ }^{\circledR} 2.5 \mathrm{~g} \mathrm{~L}^{-1}$ ) sprayed with 7day intervals, with the first spraying at 25 days after planting. Pest control, such as thrips and mites was performed with alternate 15-day interval spraying of clorfernapir (Pirate ${ }^{\circledR} 0.5 \mathrm{~mL} \mathrm{~L}^{-1}$ ) or deltamethrin (Decis $\left.{ }^{\circledR}, 0.3 \mathrm{~mL} \mathrm{~L}^{-1}\right)$, with the first spraying at 20 days after planting. Weed control was performed manually in the subplots and with hoes between the beds, always maintaining a clean area for the plants.

Several harvest were performed, because the different cycles of the treatments, as the plants were showing maturation signs (yellowing and drying in the leaves in about $2 / 3$ of the shoots). After harvesting, the bulbs were subjected to a curing process at sunlight for three days. Therefore, the plants were laid out in rows, so that the leaves of a plant would cover the plant bulbs of the next line, protecting them from direct sunlight. Subsequently, the bulbs were subjected to a curing process at shadow in a wide and ventilated area for seven days. After the curing process, the bulbs were cleaning and the shoots were removed $(1 \mathrm{~cm}$ from the bulbs) as well as the stem roots.

The characteristics evaluated were: plant emergency $(\%)$ by counting the plant number emerged at 40 days after planting (DAP); plant height $(\mathrm{cm})$ at 73 DAP by measuring the distance from the ground level up to the end of the longest leaf; number of expanded leaves per plant at 73 DAP; crop cycle (days), by counting the number of days between planting and harvest; average weight of bulbs $(\mathrm{g})$, by the ratio between the total weight and the total number of bulbs after the curing process; percentage of bulbs with bulbil differentiation (\%); average number of bulbils per bulb; total yield $\left(\mathrm{Mg} \mathrm{ha}^{-1}\right)$, by weighing the bulbs from each subplot after the curing process; and bulb classification (\%), based on the cross-sectional diameter, according to the Ordinance 242 from September 17, 1992 (MAPA, 1992) in class 3 (32 to $37 \mathrm{~mm}$ ), class 4 (37 to $42 \mathrm{~mm}$ ), class 5 (42 to $47 \mathrm{~mm}$ ), class 6 (47 to $56 \mathrm{~mm}$ ) and class 7 (larger than $56 \mathrm{~mm}$ ). The bulbs of each class were weighed and the data expressed in percentage of each class relative to the total bulbs produced.

The experiment data were submitted to analysis of variance using the software SISVAR v.5.3 (FERREIRA, 2007) and regression through the Table Curve 2D v5.01 software (JANDEL SCIENTIFIC, 1991), at significance level of $5 \%$. The averages to the planting locations and cultivars were compared by the Snedecor's F test, and the vernalization periods, when a significant equation model were not found, were graphically presented by connecting the points of the observed data, presenting the average or maximum significant value.

\section{RESULTS AND DISCUSSION}

Regarding plant emergency, there was no significant interaction between vernalization periods and cultivars. The bulb-seed pre-planting 
vernalization favored the emergence of plants, with both cultivars fitting a quadratic model. The cultivar Gigante-do-Nucleo presented an increase in emergency up to 21 days of vernalization, reaching a maximum estimated value of $99.9 \%$ of emerged

A

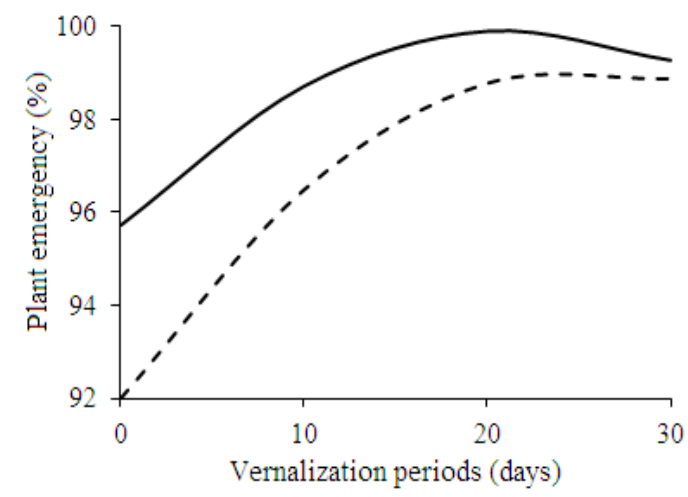

- Gigante-do-Nucleo

$\hat{\mathrm{y}}=95.7145 *+0.3909 * \mathrm{x}-0.0091 * \mathrm{x}^{2} \quad \mathrm{R}^{2}=0.98 *$

- - BRS-Hozan

$\hat{\mathrm{y}}=92.0060 *+0.5571 * \mathrm{x}-0.0109 * \mathrm{x}^{2} \mathrm{R}^{2}=0.96 *$

$\hat{y}($ Barauna $R N)=97$ a

$\hat{y}($ Governador Dix-sept Rosado RN) $=97$ a plants, while the BRS-Hozan presented an increase in emergency up to 25 days of vernalization, reaching a maximum estimated value of $99.1 \%$ of emerged plants. There was no significant difference between the planting locations (Figure 1A).

B

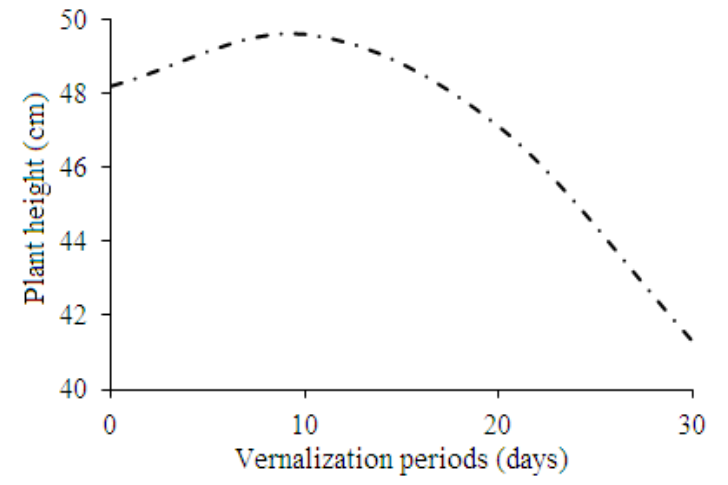

*Significant at $5 \%$ of probability $(\mathrm{p}<0.05)$; Averages with different letters differed by the $\mathrm{F}$ test $(\mathrm{p}<0.05)$.

Figure 1. Plant emergency (A) and plant height (B) of vernalizated semi-noble garlic cultivars grown.

There was a significant difference between the cultivars only in the treatments without vernalization and 10 days of vernalization, in which the cultivar Gigante-do-Nucleo presented the highest percentage of emerged plants (Table 1). According to these results and those found by Honorato et al. (2013) in Mossoró RN, both cultivars Gigante-doNucleo as BRS-Hozan did not reached $90 \%$ of emerged plants without the use of vernalization. A different result is achieved with the practice of subject the bulb-seeds to low temperatures before planting, which, according Burba (1983), stimulates the accumulation of hormones during the treatment period, modifying the hormonal balance, increasing free gibberellins and cytokinins, leading to the sprouting of the bulbil.

Table 1. Emergency average values of vernalizated semi-noble garlic cultivars.

\begin{tabular}{lcccc}
\hline Cultivars & \multicolumn{4}{c}{ Vernalization periods (days) } \\
\cline { 2 - 4 } & 0 & 10 & 20 & 30 \\
\hline Gigante-do-Nucleo & $95.62 \mathrm{a}$ & $99.00 \mathrm{a}$ & $99.62 \mathrm{a}$ & $99.37 \mathrm{a}$ \\
BRS-Hozan & $92.25 \mathrm{~b}$ & $95.75 \mathrm{~b}$ & $99.50 \mathrm{a}$ & $98.62 \mathrm{a}$ \\
\hline
\end{tabular}

Means followed by the same letters (cultivars within vernalization periods) in the column did not differ by the Snedecor's F test $(\mathrm{p}<0.05)$.

The plant height was significantly influenced by the vernalization periods and cultivars. An increase in plant height with the use of vernalization was observed up to the period of 10 days, with maximum estimated average of $49.63 \mathrm{~cm}$. The lowest average height $(41.34 \mathrm{~cm})$ was observed when the bulb-seeds were vernalized for 30 days, indicating that bulb-seed pre-planting vernalization periods above 10 days hinders their growth and development. Regarding the cultivar effect, the BRSHozan reached an average height of $49.47 \mathrm{~cm}$, while the Gigante-do-Nucleo presented $43.69 \mathrm{~cm}$. The planting locations presented no statistically significant differences in plant height (Figure 1B).

Similar result was observed by Oliveira et al. (2010), who found greater height for the BRS-Hozan compared to the Gigante-do-Nucleo, confirmed at 60, 90 and 120 DAP. Honorato (2012) also found the same results at 40,60 and 120 DAP. The difference between these cultivars are related to the inherent characteristics of each one. In general, the Gigantedo-Nucleo presents mid-sized plants and the BRSHozan presents high-sized plants, which have the potential to produce larger bulbs, since the 
production of garlic bulbs is related to the plant vegetative growth, due to the transport of nutrients and assimilates from leaves and pseudostem to the bulbs.

The interaction between periods of vernalization, cultivars and planting locations presented significant effects on the number of leaves, crop cycle, average weight of bulbs, bulbs with bulbil differentiation, number of bulbil per bulb and total yield.

In Barauna, the cultivars presented similar results related to vernalization periods, with estimated maximum values of 8.0 (Gigante-do-

A

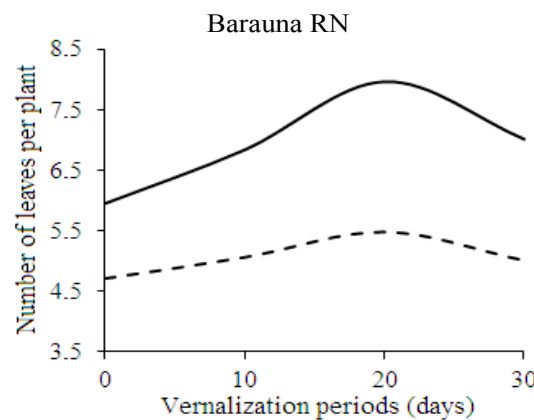

- Gigante-do-Nucleo

$\hat{y}=5.9481 *+0.0127 * x^{2}-0.0004 * x^{3} R^{2}=0.99 *$

- - - BRS-Hozan

$\hat{\mathrm{y}}=4.7137 *+0.0050 * \mathrm{x}^{2}-0.0002 * \mathrm{x}^{3} \mathrm{R}^{2}=0.98 *$

$\mathrm{C}$

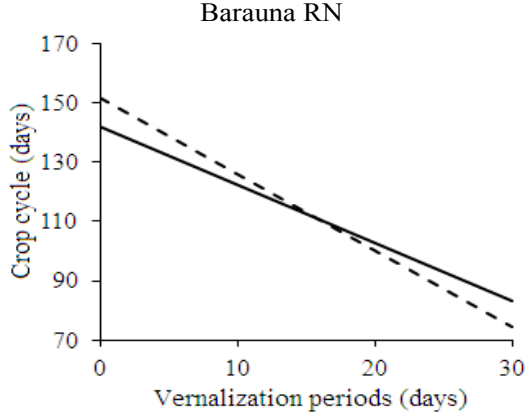

Gigante-do-Nucleo

$\hat{\mathrm{y}}=141.90^{*}-1.96^{*} \times \mathrm{R}^{2}=0.96^{*}$

- - - BRS-Hozan

$\hat{\mathrm{y}}=151.70^{*}-2.58^{*} \mathrm{x} \quad \mathrm{R}^{2}=0.92^{*}$

$\mathrm{E}$

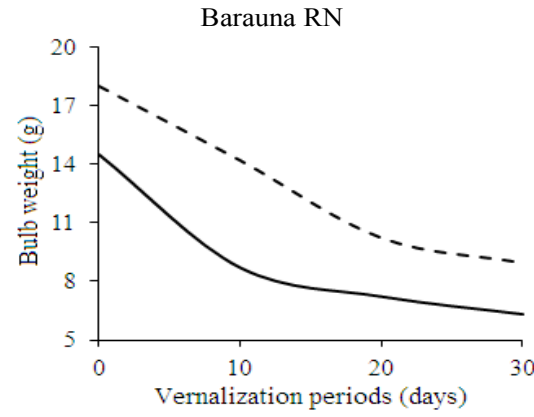

Gigante-do-Nucleo

$\hat{\mathrm{y}}^{-1}=0.0690 *+0.0007 * \mathrm{x}+0.0121 * \mathrm{x}^{0.5}$

$\mathrm{R}^{2}=0.99 *$

- - - BRS-Hozan

$\hat{\mathrm{y}}^{-1}=0.055483 *+0.000192 * \mathrm{x}^{2}-0.000004 * \mathrm{x}^{3}$ $\mathrm{R}^{2}=0.99 *$
Nucleo) and 5.5 leaves (BRS-HOZAN) per plant at 22 and 21 days of vernalization, respectively (Figure 2A). In Governador Dix-sept Rosado the cultivar Gigante-do-Nucleo showed an increase in number of leaves with the increase of the vernalization period, with estimated maximum values of 7.4 leaves per plant when the bulb-seeds were vernalized for 30 days. The BRS-Hozan fitted a quadratic model with low number of leaves, with estimated maximum values of 5.0 leaves per plant with bulb-seed vernalization of 20 days (Figure 2B). Vernalization periods longer than 20 days did not contributed to an increase in leaf production in this cultivar.

B Governador Dix-sept Rosado RN

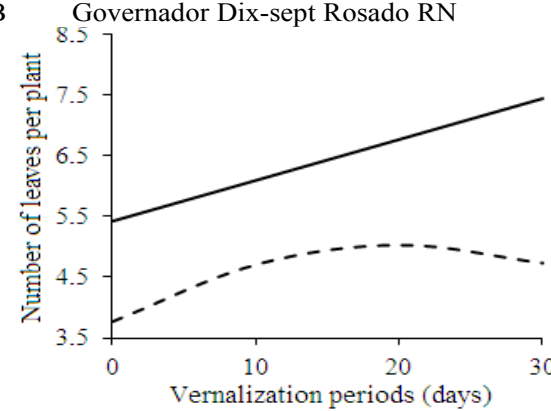

Gigante-do-Nucleo

$\hat{\mathrm{y}}=5.4250^{*}+0.0675^{*} \times \mathrm{R}^{2}=0.99 *$

- - - BRS-Hozan

$\hat{\mathrm{y}}=3.7625^{*}+0.1262 * \mathrm{x}-0.0031 * \mathrm{x}^{2} \mathrm{R}^{2}=0.99 *$

D

Governador Dix-sept Rosado RN

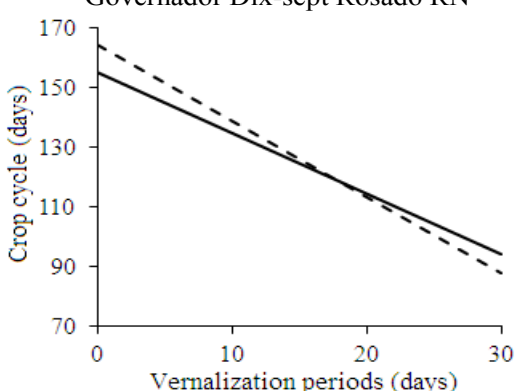

Gigante-do-Nucleo

$\hat{\mathrm{y}}=155.20^{*}-2.03 * \mathrm{x} \quad \mathrm{R}^{2}=0.99 *$

- - BRS-Hozan

$\hat{\mathrm{y}}=164.10^{*}-2.54^{*} \mathrm{x} \quad \mathrm{R}^{2}=0.97 *$

F Governador Dix-sept Rosado RN

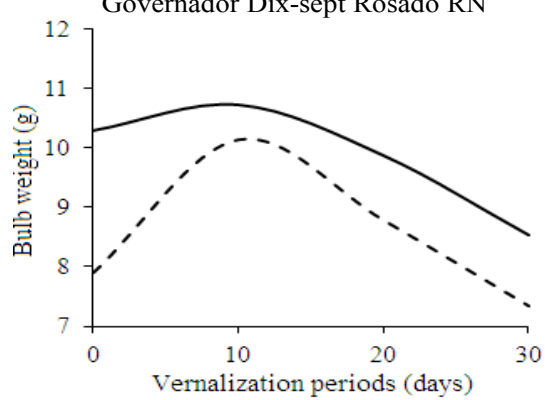

Gigante-do-Nucleo

$\hat{\mathrm{y}}^{-1}=0.0971 *-0.0018 * \mathrm{x}+0.0004 * \mathrm{x}^{1.5}$

$\mathrm{R}^{2}=0.89 *$

- - - BRS-Hozan

$\hat{\mathrm{y}}^{-1}=0.1264 *+0.0046^{*} \mathrm{x}-0.0232 * \mathrm{x}^{0.5}$

$\mathrm{R}^{2}=0.92 *$

$*=$ significant at $5 \%$ of probability $(\mathrm{p}<0.05)$.

Figure 2. Number of leaves, crop cycle and average weight of bulbs of vernalizated semi-noble garlic cultivars. 
A significant difference between cultivars was observed in all treatments. The cultivar Gigante-doNucleo had the largest number of leaves per plant. The cultivars had higher number of leaves in Barauna, regardless the vernalization periods (Table 2). Similar results for Gigante-do-Nucleo was found by Sedoguchi et al. (2002), assessing morphological characteristics of cultivars in Seropedica, RJ, with a number of leaves per plant also greater than 7.0, at 75 days after planting, in that case without vernalization. Mercer et al. (2006), evaluating the cultivar BRS-Hozan in Mid-South Parana State, found 6.1 leaves per plant at 60 days after emergence, also without bulb-seed vernalization. According to Lopes (2014), the number of leaves and their arrangement on the pseudostem, associated with plant height, are the result of the assimilatory performance over a period of time and are related to the management practices used in the crop, and may be related to the final production of the plant.

Table 2. Average values of number of leaves, crop cycles and weight of bulbs of vernalizated semi-noble garlic cultivars.

\begin{tabular}{|c|c|c|c|c|c|}
\hline \multirow[t]{2}{*}{ Locations } & \multirow[t]{2}{*}{ Cultivars } & \multicolumn{4}{|c|}{ Vernalization periods (days) } \\
\hline & & 0 & 10 & 20 & 30 \\
\hline \multirow{3}{*}{ Barauna RN } & & \multicolumn{4}{|c|}{ Number of leaves per plant } \\
\hline & Gigante-do-Nucleo & $6.00 \mathrm{aA}$ & $6.75 \mathrm{aA}$ & $8.00 \mathrm{aA}$ & $7.00 \mathrm{aA}$ \\
\hline & BRS-Hozan & $4.75 \mathrm{bA}$ & $5.00 \mathrm{bA}$ & $5.50 \mathrm{bA}$ & $5.00 \mathrm{bA}$ \\
\hline \multirow[t]{2}{*}{ Gov. D. Rosado RN } & Gigante-do-Nucleo & $5.50 \mathrm{aA}$ & $5.50 \mathrm{aB}$ & $6.75 \mathrm{aB}$ & $7.50 \mathrm{aA}$ \\
\hline & BRS-Hozan & $3.75 \mathrm{bB}$ & $4.75 \mathrm{bA}$ & $5.00 \mathrm{bA}$ & $4.75 \mathrm{bA}$ \\
\hline & & \multicolumn{4}{|c|}{ Crop cycle (days) } \\
\hline \multirow[t]{2}{*}{ Barauna RN } & Gigante-do-Nucleo & $146 \mathrm{bB}$ & $119 \mathrm{aB}$ & $97 \mathrm{aB}$ & $88 \mathrm{aB}$ \\
\hline & BRS-Hozan & $161 \mathrm{aB}$ & $115 \mathrm{bB}$ & $94 \mathrm{bB}$ & $82 \mathrm{bB}$ \\
\hline \multirow[t]{2}{*}{ Gov. D. Rosado RN } & Gigante-do-Nucleo & $154 \mathrm{bA}$ & $136 \mathrm{aA}$ & $116 \mathrm{aA}$ & $93 \mathrm{aA}$ \\
\hline & BRS-Hozan & $168 \mathrm{aA}$ & $136 \mathrm{aA}$ & $107 \mathrm{bA}$ & $93 \mathrm{aA}$ \\
\hline \multirow{3}{*}{ Barauna RN } & & \multicolumn{4}{|c|}{ Bulb weight (g) } \\
\hline & Gigante-do-Nucleo & $14.50 \mathrm{bA}$ & $8.51 \mathrm{bB}$ & $7.62 \mathrm{bB}$ & $6.02 \mathrm{bB}$ \\
\hline & BRS-Hozan & $17.88 \mathrm{aA}$ & $14.55 \mathrm{aA}$ & $9.82 \mathrm{aA}$ & $9.04 \mathrm{aA}$ \\
\hline \multirow[t]{2}{*}{ Gov. D. Rosado RN } & Gigante-do-Nucleo & $10.21 \mathrm{aB}$ & $11.00 \mathrm{aA}$ & $9.43 \mathrm{aA}$ & $8.72 \mathrm{aA}$ \\
\hline & BRS-Hozan & $7.87 \mathrm{bB}$ & $10.33 \mathrm{aB}$ & $8.29 \mathrm{aB}$ & $7.60 \mathrm{aB}$ \\
\hline
\end{tabular}

Means followed by the same lowercase (cultivars within vernalization periods and locations) and capital (locations within vernalization periods and cultivars) letters in the same column did not differ by the Snedecor's F test ( $<<0.05)$.

A reduction in the crop cycle was observed with an increase in the vernalization period in both location and cultivars. The estimated maximum cycles were 141.9 (Gigante-do-Nucleo) and 151.7 (BRS-Hozan) days in Barauna and 155.2 (Gigantedo-Nucleo) and 164.1 (BRS-Hozan) days in Governador Dix-Sept Rosado, without vernalization. The estimated minimum cycles were 83.1 (Gigantedo-Nucleo) and 74.3 (BRS-Hozan) days in Barauna and 94.3 (Gigante-do-Nucleo) and 87.9 (BRSHozan) days in Governador Dix-Sept Rosado, with bulbs-seeds vernalized for 30 days (Figures $2 \mathrm{C}$ and 2D). Cycle reduction with vernalization is also observed in other cultivars and growing regions of vernalizated garlic (LOPES, 2014). This practice represents less investment in irrigation, fertilization, pesticides and hand labor, since these factors increase the crop cost of this vegetable. However, a drastic reduction in the cycle, resulted from an increase in vernalization time, may lead to a reduction in bulb size, hindering the production, because the early bulbil differentiation (FERREIRA,
1989).

Regarding the effects between cultivars and planting locations, the cultivars presented longer cycle, regardless of vernalization periods, in the Governador Dix-sept Rosado, where the BRS-Hozan reached the longest crop cycle, while the Gigante-doNucleo, in Barauna, had a crop cycle of 161 days, both without vernalization (Table 2).

Regarding the influence of the vernalization periods in the average bulb weight, the cultivars had similar results in Barauna, with a decrease in weight bulbs with an increase in the vernalization period, presenting estimated maximum values of 14.49 (Gigante-do-Nucleo) and 18.02 g (BRS-Hozan) without vernalization and minimum of 6.33 (Gigante -do-Nucleo) and $8.94 \mathrm{~g}$ (BRS-Hozan) when vernalized for 30 days (Figure 2E). The bulb weight of the cultivars in Governador Dix-sept Rosado was increasing up to a maximum estimated average of 10.79 (Gigante-do-Nucleo) with 7 days of vernalization, and $10.15 \mathrm{~g}$ (BRS-Hozan) with 10 days of vernalization, with a decreases from there, 
reaching at 30 days of vernalization, estimated minimums of 8.53 (Gigante-do-Nucleo) and $7.35 \mathrm{~g}$ (BRS-Hozan) (Figure 2F).

The interaction between cultivars and planting locations in each vernalization period, showed that the cultivar BRS-Hozan had better performance than the Gigante-do-Nucleo, presenting higher total bulbs in Barauna, however, they differed only in the treatment without vernalization in Governador Dixsept Rosado, where the Gigante-do-Nucleo had better performance (Table 2). Lower average bulb weight results were found by Honorato et al. (2013), without bulb-seed vernalization, with bulbs with 9.14 g (Gigante-do-Nucleo) and $9.11 \mathrm{~g}$ (BRS-Hozan). Oliveira et al. (2010) found different values in Diamantina, MG, with average bulb weight of 15.61 $\mathrm{g}$ (Gigante-do-Nucleo) and $12.61 \mathrm{~g}$ (BRS-Hozan), values that were lower than those found in the Western Mesoregion of Rio Grande do Norte State, Brazil.

Regarding the vernalization periods influence on the percentage of bulbs with bulbil differentiation
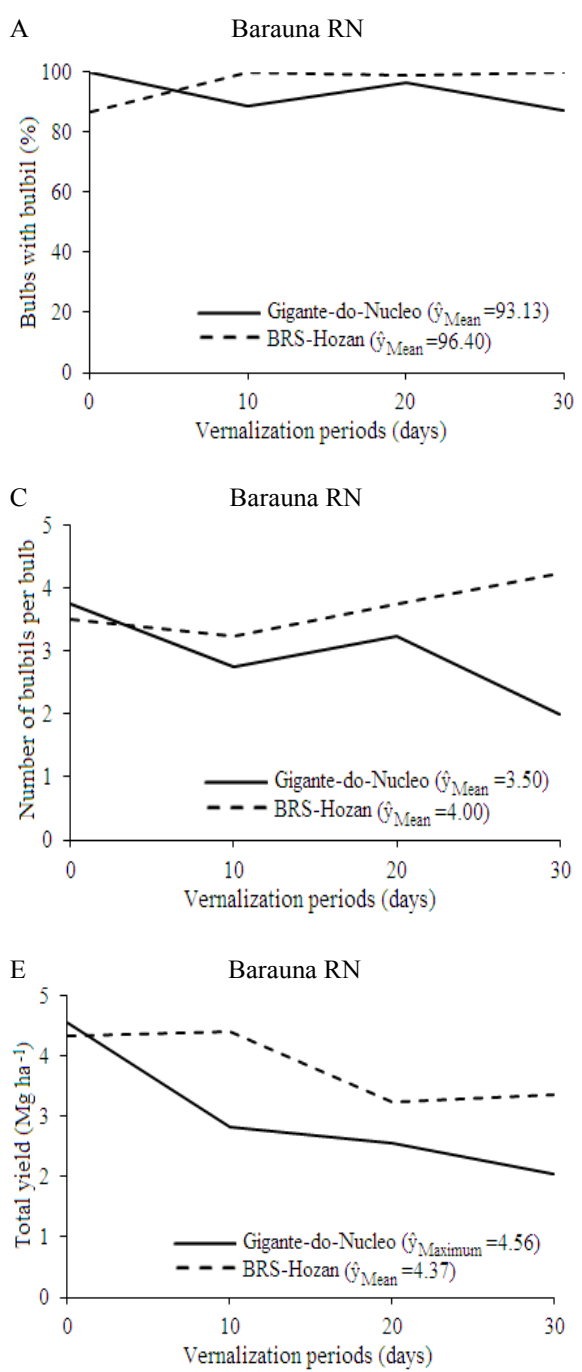

of each cultivar and planting location (Figures 3A and $3 \mathrm{~B}$ ), the cultivar Gigante-do-Nucleo presented no significant effect in Barauna, however, it had bulbs with bulbil differentiation in $100 \%$ of the plants without vernalization. On the other hand, a significant effect of vernalization periods in this cultivar was observed in Governador Dix-Sept Rosado, especially in the treatments without vernalization and with 10 and 30 days of vernalization, which were superior to the treatment with 20 days of vernalization.

The BRS-Hozan also had no significant difference between the vernalization periods in Barauna, however, it had bulbs with bulbil differentiation in $100 \%$ of the plants with 10 and 30 days of vernalization. This cultivar had $12.82 \%$ bulbs with bulbil differentiation in Governador Dixsept Rosado, without vernalization, value lower than the treatment with 10,20 and 30 days of vernalization, in which the 20 and 30 days had lower values than the 10 days of vernalization.
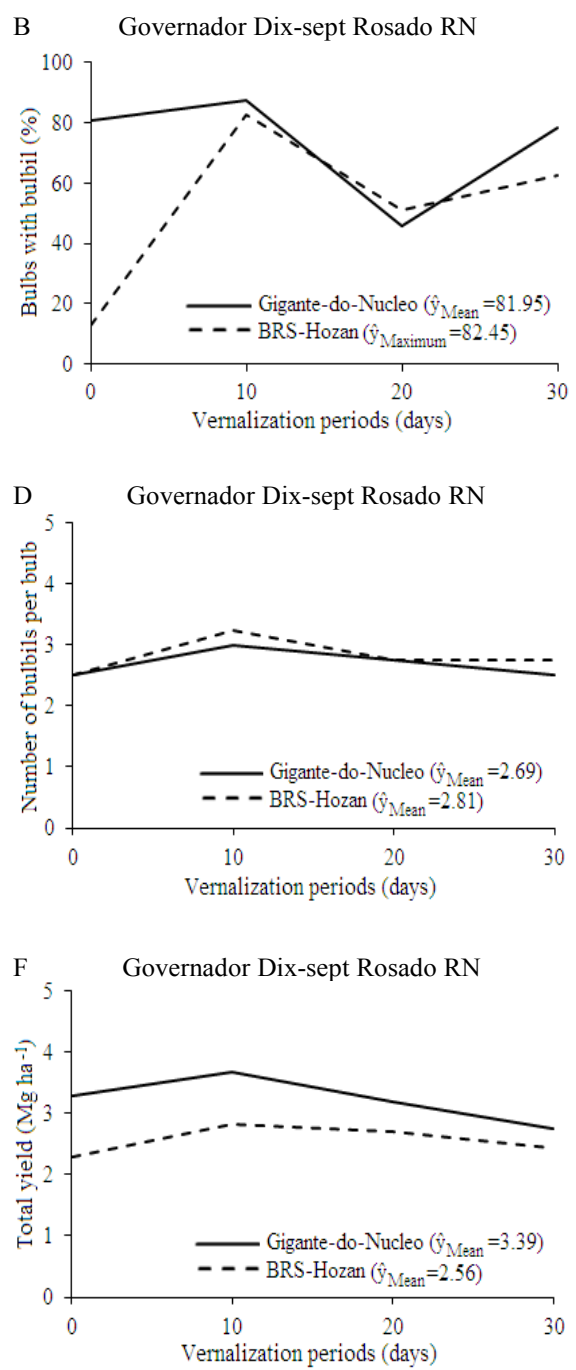

Figure 3. Percentage of bulbs with bulbil differentiation, number of bulbils per bulb and total yield of vernalizated seminoble garlic cultivars. Minimum significant difference between vernalization periods of 0.61 at $p<0.05$. 
Regarding the percentage of bulbs with bulbil differentiation of the cultivars in each vernalization period and planting location (Table 3), the Gigantedo-Nucleo without vernalization, with 10, 20 and 30 days of vernalization in Barauna was statistically equal to the BRS-Hozan. However, in Governador Dix-sept Rosado, the Gigante-do-Nucleo (80.35\%) was superior to the BRS-Hozan (12.82\%) in bulbs with bulbil differentiation without vernalization. Honorato et al. (2013) in Mossoró RN, found values of bulbs with bulbil differentiation lower than those found in the present study for Gigante-do-Nucleo $(27.20 \%)$ and BRS-Hozan $(34.65 \%)$, percentages that could be raised using bulb-seed vernalization in that location, as was observed in Governador Dixsept Rosado.

Table 3. Mean values of percentage of bulbs with bulbil differentiation, number of bulbils per bulb and total yield of vernalizated semi-noble garlic cultivars.

\begin{tabular}{|c|c|c|c|c|c|}
\hline \multirow[t]{2}{*}{ Locations } & \multirow[t]{2}{*}{ Cultivars } & \multicolumn{4}{|c|}{ Vernalization periods (days) } \\
\hline & & 0 & 10 & 20 & 30 \\
\hline \multirow{3}{*}{ Barauna RN } & & \multicolumn{4}{|c|}{ Bulbs with bulbil differentiation (\%) } \\
\hline & Gigante-do-Nucleo & $100.00 \mathrm{aA}$ & $88.70 \mathrm{aA}$ & $96.72 \mathrm{aA}$ & $87.12 \mathrm{aA}$ \\
\hline & BRS-Hozan & $86.60 \mathrm{aA}$ & $100.00 \mathrm{aA}$ & $99.00 \mathrm{aA}$ & $100.00 \mathrm{aA}$ \\
\hline \multirow[t]{2}{*}{ Gov. D. Rosado RN } & Gigante-do-Nucleo & $80.35 \mathrm{aB}$ & $87.45 \mathrm{aA}$ & $45.77 \mathrm{aB}$ & $78.05 \mathrm{aA}$ \\
\hline & BRS-Hozan & $12.82 \mathrm{bB}$ & $82.45 \mathrm{aA}$ & $51.17 \mathrm{aB}$ & $62.47 \mathrm{aB}$ \\
\hline \multirow{3}{*}{ Barauna RN } & & \multicolumn{4}{|c|}{ Number of bulbils per bulb } \\
\hline & Gigante-do-Nucleo & $3.75 \mathrm{aA}$ & $2.75 \mathrm{aA}$ & $3.25 \mathrm{aA}$ & $2.00 \mathrm{bA}$ \\
\hline & BRS-Hozan & $3.50 \mathrm{aA}$ & $3.25 \mathrm{aA}$ & $3.75 \mathrm{aA}$ & $4.25 \mathrm{aA}$ \\
\hline \multirow[t]{2}{*}{ Gov. D. Rosado RN } & Gigante-do-Nucleo & $2.50 \mathrm{aB}$ & $3.00 \mathrm{aA}$ & $2.75 \mathrm{aA}$ & $2.50 \mathrm{aA}$ \\
\hline & BRS-Hozan & $2.50 \mathrm{aB}$ & $3.25 \mathrm{aA}$ & $2.75 \mathrm{aB}$ & $2.75 \mathrm{aB}$ \\
\hline \multirow{3}{*}{ Barauna RN } & & \multicolumn{4}{|c|}{ Total yield $\left(\mathrm{Mg} \mathrm{ha}^{-1}\right)$} \\
\hline & Gigante-do-Nucleo & $4.56 \mathrm{aA}$ & $2.82 \mathrm{bB}$ & $2.57 \mathrm{bB}$ & $2.06 \mathrm{bB}$ \\
\hline & BRS-Hozan & $4.33 \mathrm{aA}$ & $4.42 \mathrm{aA}$ & $3.23 \mathrm{aA}$ & $3.37 \mathrm{aA}$ \\
\hline \multirow[t]{2}{*}{ Gov. D. Rosado RN } & Gigante-do-Nucleo & $3.28 \mathrm{aB}$ & $3.69 \mathrm{aA}$ & $3.20 \mathrm{aA}$ & $2.76 \mathrm{aA}$ \\
\hline & BRS-Hozan & $2.28 \mathrm{bB}$ & $2.82 \mathrm{bB}$ & $2.70 \mathrm{bB}$ & $2.43 \mathrm{aB}$ \\
\hline
\end{tabular}

Means followed by the same lowercase (cultivars within vernalization periods and locations) and capital (locations within vernalization periods and cultivars) letters in the same column did not differ by the Snedecor's F test $(\mathrm{p}<0.05)$.

Regarding the planting locations, both cultivars presented higher percentages of bulbs with bulbil differentiation in Barauna (Table 3). This characteristic indicates a better adaptability and response to vernalization of garlic cultivars in a given planting location. Therefore, the cultivar Gigante-do-Nucleo proved to be adapted to the edaphoclimatic conditions of Barauna, with $100 \%$ of bulbs with bulbil differentiation without the use of vernalization, while the BRS-Hozan proved to be little adapted to the planting locations, requiring vernalization to improve its adaptation.

Regarding the influence of vernalization periods of each cultivar in each planting locations on the number of bulbil per bulb (Figure 3C and 3D), the cultivar Gigante-do-Nucleo in Barauna had the highest number of bulbils (3.75 bulbils per bulb) with no vernalization, however, it had no statistically difference from the treatment with 20 days vernalization. On the other hand, the Gigante-doNucleo had no differences between vernalization periods in Governador Dix-Sept Rosado. The BRSHozan had significant differences between the vernalization periods in Barauna, especially in the treatment with 30 days of vernalization ( 4.25 bulbils per bulb). However, this cultivar presented no significant differences between vernalization periods in Governador Dix-Sept Rosado, with mean value of 3.25 bulbils, using bulb-seed vernalization of 10 days.

Regarding the cultivars in each vernalization period and planting location (Table 3), significant difference between cultivars were found in Barauna only in the treatment with 30 days of vernalization. The BRS-Hozan stood out with 4.25 bulbils per bulb. No differences between cultivars were found in Governador Dix-sept Rosado in any treatment, with an average of 2.75 bulbils per bulb. Regarding the planting locations, both cultivars presented higher number of bulbils per bulb in Barauna.

The average number of bulbils (12 bulbils per bulb) found in the Western Mesoregion of Rio Grande do Norte State was below the average of regions where the cultivars Gigante-do-Nucleo and BRS-Hozan are adapted, therefore, in both Barauna and Governador Dix-sept Rosado, the differentiation of these cultivars was incomplete, regardless of the use of vernalization. This difference may be due to the adaptability of these cultivars to local climatic conditions (temperature and photoperiod), although 
other factors such as soil fertility and irrigation management may interact, influencing the final performance of the crop.

The number of bulbils per bulb and bulb average weight are very important characteristics for commercialization of garlic. Large bulbs with small number of bulbils, have higher prices in the markets. Therefore, cultivars with low number of bulbils per bulb is undesirable by producers, since they reduce their multiplication capacity and raises the cost of bulb-seeds per area (SOARES, 2013).

Regarding the vernalization period influence in the total yield of the cultivars in each crop location (Figures 3E and 3F), the Gigante-do-Nucleo had higher total yield $\left(4.56 \mathrm{Mg} \mathrm{ha}^{-1}\right)$ in Barauna with no vernalization, with bulbs distributed commercially (Table 4) in the classes 3 (39.7\%), 4 (19.14\%) and 5 (3.87\%). In Governador Dix-sept Rosado, this cultivar had greater yield performance with 10 days of vernalization, reaching $3.69 \mathrm{Mg} \mathrm{ha}^{-1}$, within the classes $3(36.71 \%), 4(5.53 \%)$ and $5(1.07 \%)$ (Table $4)$, although had been significantly influenced only in treatment with 30 days of vernalization (2.76 $\mathrm{Mg} \mathrm{ha}^{-1}$ ). The BRS-Hozan had the highest yield in Barauna with 10 days of vernalization (4.42 $\mathrm{Mg} \mathrm{ha}^{-1}$ ). However, in Governador Dix-sept Rosado there was no significant effect of vernalization periods on total yield, which had an average of $2.56 \mathrm{Mg} \mathrm{ha}^{-1}$. This cultivar had also the highest percentage of commercial bulbs distributed in the classes $3(51.03 \%), 4(17.85 \%)$ and $5(8.96 \%)$, in Barauna, without bulb-seed vernalization (Table 4). Results that differ from those found in Mossoró $\mathrm{RN}$, where these cultivars had percentage of commercial bulbs lower than $40 \%$ without vernalization, therefore, a percentage of reject (bulbs with diameter less than $32 \mathrm{~mm}$ ) greater than $60 \%$ (HONORATO et al., 2013).

Table 4. Bulbs classification of vernalizated semi-noble garlic cultivars.

\begin{tabular}{|c|c|c|c|c|c|c|c|c|}
\hline \multirow{3}{*}{$\begin{array}{l}\text { Vernalization } \\
\text { Periods(days) }\end{array}$} & \multicolumn{8}{|c|}{ Bulb Classification $(\%)^{1}$} \\
\hline & Reject & $\mathrm{C} 3$ & $\mathrm{C} 4$ & $\mathrm{C} 5$ & Reject & $\mathrm{C} 3$ & $\mathrm{C} 4$ & $\mathrm{C} 5$ \\
\hline & \multicolumn{4}{|c|}{ Barauna RN } & \multicolumn{4}{|c|}{ Governador Dix-sept Rosado RN } \\
\hline \multicolumn{9}{|c|}{ cv. Gigante-do-Nucleo } \\
\hline 0 & 37.29 & 39.70 & 19.14 & 3.87 & 64.28 & 31.65 & 4.07 & 0.00 \\
\hline 10 & 85.31 & 14.17 & 0.52 & 0.00 & 56.69 & 36.71 & 5.53 & 1.07 \\
\hline 20 & 97.65 & 2.35 & 0.00 & 0.00 & 74.01 & 24.22 & 1.77 & 0.00 \\
\hline 30 & 96.66 & 3.34 & 0.00 & 0.00 & 90.22 & 9.78 & 0.00 & 0.00 \\
\hline \multicolumn{9}{|c|}{ cv. BRS-Hozan } \\
\hline 0 & 22.16 & 51.03 & 17.85 & 8.96 & 49.85 & 50.15 & 0.00 & 0.00 \\
\hline 10 & 68.78 & 30.11 & 1.11 & 0.00 & 95.02 & 4.98 & 0.00 & 0.00 \\
\hline 20 & 92.62 & 7.35 & 0.00 & 0.00 & 100.00 & 0.00 & 0.00 & 0.00 \\
\hline 30 & 90.13 & 9.40 & 0.47 & 0.00 & 99.27 & 0.73 & 0.00 & 0.00 \\
\hline
\end{tabular}

${ }^{1}$ Bulb size based on cross-sectional diameter: Reject (<32 mm), C3 (32 to $37 \mathrm{~mm}$ ), C4 (37 to $42 \mathrm{~mm}$ ), C5 (42 to $47 \mathrm{~mm}$ ).

Regarding the influence of the cultivars in each vernalization period and planting location in the total yield (Table 3), there was no difference between cultivars without vernalization in Barauna. However, with 10, 20 and 30 days of vernalization, the BRSHozan had higher yields compared to the Gigante-do -Nucleo. In Governador Dix-sept Rosado, the highest yields were achieved with the Gigante-do-Nucleo without vernalization, with 10 and 20 days of vernalization, and with 30 days of vernalization it was statistically equal the BRS-Hozan. In general, the cultivars had higher total yield in Barauna.

The total yield of the cultivars in both locations were close to those observed by Silva et al. (2008), who found 4.86 $\mathrm{Mg} \mathrm{ha}^{-1}$ for the Gigante-doNucleo and $3.85 \mathrm{Mg} \mathrm{ha}^{-1}$ for the BRS-Hozan, in the Cerrado biome. Moreover, Resende et al. (2013) found 4.1 Mg ha ${ }^{-1}$ for the Gigante-do-Nucleo and 3.1 $\mathrm{Mg} \mathrm{ha}^{-1}$ for the BRS-Hozan, relating the high yield results to the low temperatures $\left(13.5\right.$ to $\left.24.5^{\circ} \mathrm{C}\right)$ and high altitude $(1.025 \mathrm{~m})$ of the experiment location (Guarapuava PR), which was very different from those in Barauna and Governador Dix-sept Rosado.

The differences between cultivars occur due to the variations in edaphoclimatic conditions in which they are grown (TRANI et al., 2005). In the present study, climate differences in planting locations were observed and certainly influenced the results. The average temperatures during the experiments were $26.6^{\circ} \mathrm{C}$ in Barauna and $28.6^{\circ} \mathrm{C}$ in Governador Dix-Sept Rosado, a difference of $2.0^{\circ} \mathrm{C}$; the relative humidity was $59.1 \%$ in Barauna and $55.9 \%$ in Governador Dix-Sept Rosado, a difference of 3.2 percentage points; and the altitude was $120 \mathrm{~m}$ in Barauna and $34 \mathrm{~m}$ in Governador Dix-sept Rosado, a difference of $86 \mathrm{~m}$.

The altitude was an important point, since both cultivars presented better adaptation to Barauna, proving that the crop development and production are compromised at low altitudes. The relevance of the altitude factor on garlic yield can be confirmed by Feitosa et al. (2009), who evaluated the yield of ten garlic cultivars in Nova Friburgo (altitude of $1.100 \mathrm{~m}$ ), Petropolis (altitude of $1.100 \mathrm{~m}$ ), Paty do Alfeles (altitude of $700 \mathrm{~m}$ ) and Seropedica (altitude of $30 \mathrm{~m}$ ), in Rio de Janeiro State, and observed that the cultivars presented different yields depending on the conditions of planting locations, with the altitude as the decisive factor for adaptability of some cultivars. In their study, all cultivars had lower yield 
at lower altitude, the BRS-Hozan in Seropedica, for example, produced $2.08 \mathrm{Mg} \mathrm{ha}^{-1}$, lower than that obtained in Barauna and Governador Dix-sept Rosado in the present study.

These results confirm that the cultivars present differences depending on the edaphoclimatic factors to which they are submitted. Techniques that provide satisfactory results in one place, such as bulb -seed vernalization, may not provide the same results in another. In Barauna and Governador Dix-sept Rosado, the reductions observed in the evaluated characteristics with vernalization caused plants absence of sufficient time to reach full vegetative development. Consequently, the evaluated characteristics of average weight of bulbs and total yield were lower than those found in other garlic producing regions, indicating the need for more researches evaluating the adaptability of garlic cultivars to this technique for the climatic conditions in which this study was conducted.

\section{CONCLUSIONS}

In Barauna, the cultivar Gigante-do-Nucleo proved to be adapted, with yield of $4.56 \mathrm{Mg} \mathrm{ha}^{-1}$ without vernalization, while the BRS-Hozan had yield of $4.42 \mathrm{Mg} \mathrm{ha}^{-1}$ when vernalized by 10 days at pre-planting.

In Governador Dix-sept Rosado, the vernalization of up to 10 days improved the adaptation of both cultivars, however without significant yield increases.

The use of vernalization improved adaptation of cultivars in the planting locations, facilitating the emergence of plants, increasing plant height and number of leaves, however, not promoting significant yield increases, therefore, this technology should not be used for produce this type of garlic in this region.

\section{AKNOWLEDGEMENTS}

The authors thank the National Counsel of Technological and Scientific Development (CNPq) for the financial support to carry out this research project, and the Farms Santa Luzia (Barauna RN) and Santana (Governador Dix-sept Rosado RN) for logistic support in the experiments.

\section{REFERENCES}

ALLEN, R. G. et al. Crop evapotranspiration: guidelines for computing crop water requirements. Rome: FAO, 1998, 297p. (Irrigation and Drainage Paper, 56).

BURBA, J. L. Efeitos do manejo do alho semente (Allium sativum L.) sobre a dormência, crescimento e produção do cultivar Chonan. 1983. 112 f. Dissertação (Mestrado em Fitotecnia: Área de Concentração em Olericultura) - Universidade Federal de Viçosa, Viçosa, 1983.

CAVALCANTI, F. J. A. Recomendações de adubação para o estado de Pernambuco: $2^{\mathrm{a}}$ aproximação. 3. ed. Recife: Instituto Agronômico de Pernambuco, 2008. 212 p.

CUNHA, C. P. Desenvolvimento de marcadores microssatélites e caracterização da diversidade genética molecular de acessos de alho (Allium sativum L.). 2011. 91 f. Dissertação (Mestrado em Agronomia: Área de Concentração em Genética e Melhoramento de Plantas) - Escola Superior de Agricultura “Luiz de Queiroz”, Piracicaba, 2011.

EMBRAPA. Centro Nacional de Pesquisa de Solos. Sistema brasileiro de classificação de solos. 2. ed. Rio de Janeiro: Embrapa Solos, 2006. 306 p.

FEITOSA, H. O. et al. Produtividade do alho em diferentes regiões do Rio de janeiro, sob sistema orgânico de produção. Agropecuária Técnica, Areia, v. 30, n. 1, p. 13-20, 2009.

FERREIRA, D. F. SISVAR Versão 5.3. Departamento de Ciências Exatas. Lavras-MG: UFLA, 2007.

FERREIRA, F. A. Desenvolvimento de cultivares de alho (Allium sativum L.) submetidos à superação artificial da dormência. 1989. 101 f. Tese (Doutorado em Fitotecnia: Área de Concentração em Produção Vegetal) - Universidade Federal de Viçosa, Viçosa, 1989.

HONORATO, A. R. F. et al. Avaliação de cultivares de alho na região de Mossoró. Revista Caatinga, Mossoró, v. 26, n. 3, p. 80-88, 2013.

HONORATO, A. R. F. Avaliação de cultivares de alho na região de Mossoró. 2012. 59 f. Dissertação (Mestrado em Fitotecnia: Área de Concentração em Agricultura Tropical) - Universidade Federal Rural do Semi-Árido, Mossoró, 2012.

JANDEL SCIENTIFIC. Table Curve: curve fitting software. Corte Madera, CA: Jandel Scientific. 1991. $280 \mathrm{p}$.

LIMA, C. P. et al. Produtividade e características comerciais do alho vernalizado em função de doses de nitrogênio. Científica, Jaboticabal, v. 36, n. 1, p. 48-55, 2008.

LOPES, W. A. R. Produção e qualidade de alho nobre submetido a diferentes períodos de vernalização e épocas de plantio em Baraúna, RN. 
2014. 112 f. Tese (Doutorado em Fitotecnia: Área de Concentração em Agricultura Tropical) Universidade Federal Rural do Semi-Árido, Mossoró, 2014.

LUCINI, M. A. Situação fitossanitária do alho no Brasil. Nosso Alho, Brasília, n. 19, p. 22-29, 2014.

MACÊDO, F. S.; SOUZA, R. J.; SILVA, E. C. Exigências climáticas. In: SOUZA, R. J.; MACÊDO, F. S. (Ed.). Cultura do alho: tecnologias modernas de produção. Lavras: UFLA, 2009. cap. 3, p. 29-38.

MAPA - MINISTÉRIO DA AGRICULTURA, PECUÁRIA E ABASTECIMENTO. Portaria $\mathbf{N}^{\circ}$ 242 de 17/09/1992. 1992. Disponível em: <www.agricultura.gov.br> Acesso em: 11 dez. 2012.

MERCER, R. M. et al. Performance produtiva de cultivares de alho seminobres na região Centro-Sul do Paraná. In: CONGRESSO BRASILEIRO DE OLERICULTURA, 46., 2006, Goiânia. Anais... Brasília: Associação Brasileira de Horticultura, 2006. 1 CD-ROM.

OLIVEIRA, F. L. et al. Características agronômicas de cultivares de alho em Diamantina. Horticultura Brasileira, Brasília, v. 28, n. 3, p. 355-359, 2010.

RESENDE, F. V.; DUSI, A. N.; MELO, W. F. Recomendações básicas para a produção de alho em pequenas propriedades. Brasília: Embrapa/ CNPH, 2004. 12 p. (Comunicado Técnico, 22).

RESENDE, J. T. V. et al. Caracterização morfológica, produtividade e rendimento comercial de cultivares de alho. Horticultura Brasileira, Brasília, v. 3, n. 1, p. 157-162, 2013.

SEDOGUCHI, E. T. et al. Características morfológicas, de produção e efeitos da vernalização sobre cultivares de alho em duas épocas de plantio em Seropédica-RJ. Agronomia, Seropédica, v. 36, n. $1 / 2$, p. 42-47, 2002.

SILVA, K. M. P.; LEITE, R. S. A.; RESENDE, F. V. Cultivares de alho comum para sistemas orgânicos de produção nas condições do cerrado. In: CONGRESSO BRASILEIRO DE OLERICUlTURA, 48., 2008, Maringá. Anais... Brasília: Associação Brasileira de Horticultura, 2008. 1 CD-ROM.

SOARES, A. M. Avaliação de cultivares de alho no município de Governador Dix-sept RosadoRN. 2013. 104 f. Dissertação (Mestrado em Fitotecnia: Área de Concentração em Agricultura Tropical) - Universidade Federal Rural do Semiárido, Mossoró, 2013.
SPOTO, M. H. F.; GUTIERREZ, A. S. D. O poder de condimentação do alho. Nosso Alho, Brasília, n. 13 , p. 23-26, 2012.

TRANI, P. E. et al. Avaliação dos acessos de alho pertencentes à coleção do Instituto Agronômico de Campinas. Horticultura Brasileira, Brasília, v. 23, n. 4, p. 935-939, 2005. 